\title{
Effect of alkali treated and untreated cellulose fibers and human hair on FTIR and tensile properties for composite material applications
}

\author{
Selvakumar Kathiresan ${ }^{1}$ (D) Omkumar Meenakshisundaram ${ }^{2}$
}

Received: 26 August 2020 / Accepted: 17 January 2022

Published online: 08 February 2022

(c) The Author(s) 2022 OPEN

\begin{abstract}
In recent years, the application of natural fiber reinforced polymer composite is rapidly increasing in different parts of the world due to its light weight, low cost, availability and feasibility of easy fabrication. This article focuses on the investigation of the physical and mechanical properties of natural fibers such as human hair, Sterculia foetida, delonix regia and caryotta obtusa fibers in terms of the analysis of the suitability of reinforcement material in composites. Untreated fibers were compared with $\mathrm{NaOH}$ treated fibers. Compositional analysis from Fourier Transform Infra-red Spectroscopy, tensile properties such as tensile strength, tensile modulus and percentage elongation of both untreated and treated fibers are discussed in detail. The properties of these natural fibers were compared with those of other natural fibers. The scope of addition of human hair, sterculia foetida, and delonix regia and caryotta obtusa fibers as reinforcement material in polymer composites were reported.
\end{abstract}

Keywords Natural fibers · Alkali treatment · Single fiber testing · Tensile properties · Fourier transform infra-red spectroscopy

\section{Introduction}

Design of smart materials encompasses the selection of advanced materials that play a major role in the fabrication of new products and their performance. Composite materials offer definite advantages over metallic and nonmetallic parts due to high strength to weight ratio, light weight and high resistance to corrosion. Hence these materials are widely used in industrial applications. Reinforcement material used in composite may be either synthetic or natural fibers. Polymer composite with synthetic fibers such as glass, kevlar, aramid, etc. show good mechanical properties but the application is limited due to the growth of natural fiber reinforced polymer composite (NFRPC) during the past five years [1]. The evolution of NFRPC material in various applications has opened up new opportunities to various manufactures to use alternative materials for their products in the process of reducing environmental pollution, greenhouse gas emissions, cost reduction and increase in the efficiency of the product $[2,3]$. Automotive and aerospace industries have been vigorously manufacturing the various natural fiber reinforced parts for their interior components [4]. The mechanical and damage properties of raw materials of composite materials have a major impact in enhancement of material quality [5]. Moisture penetration inside the composites resulting in swelling of the fiber. Natural fibers are hydrophilic in nature which has many number of hydroxyl groups directly attached to the water molecule by hydrogen bond. High moisture absorption and the poor compatibility between

$\triangle$ Selvakumar Kathiresan, selvaanr@gmail.com; Omkumar Meenakshisundaram, omkumar2000@yahoo.com|'Department of Mechanical Engineering, Bharath Institute of Higher Education and Research, Chennai 600073 , India. ${ }^{2}$ Department of Manufacturing Engineering, CEG, Anna University, Chennai, India 600025.

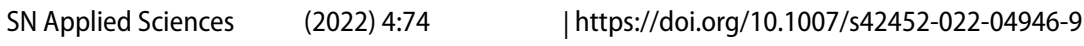


the fiber and matrix have led to a lack of interlocking of fiber with matrix. Due to this, the interface between fiber and matrix become weaker which results in decrease in the mechanical properties of the composite materials. Therefore, to improve the interface properties and bonding relationship between the fiber and matrix appropriate surface modification of the natural fibers are considered [6-8]. Modification of the fiber surface with chemicals results in variations in the tensile properties as a result of the eradication of the fiber constituents or shrinkage of cell wall [9]. Alkali treatment is widely used for modifying the structure of the fibers. Sodium Hydroxide $(\mathrm{NaOH})$ is a common alkali used for breaking down the hydroxyl $(\mathrm{OH})$ groups and the highly packed crystalline structure into new forms of amorphous network structure. It also removes certain compositions of fiber like hemicelluloses, lignin, waxes and oils that increases in the surface roughness of the fiber [10]. Further, the alkali treatment increases the surface area of the fiber that promotes the adhesion and interlocking of the fiber with matrix thus resulting in better strength properties of the composites.

Sterculia Foetida is soft wooded tall and straight tree belonging to the sterculiaceae family that can grow up to $35 \mathrm{~m}$. The chemical composition of the Sterculia foetida is $30 \%$ Cellulose, $16 \%$ Hemicellulose and $45.3 \%$ of Lignin [11]. The alkaline treatment increases the exposure of its cellulose content resulting in increase in surface roughness of the fiber which ensures the interlocking of the fiber with polymer. Teli et al. (2018) reported that the sterculia foetida fruit shell extract had good ultra violet protection properties with potential for use as a reinforcement material with polymer matrix [12]. Delonix regia Shown in Fig. $1 \mathrm{c}$ is a type of flowering plant belonging to the family of Fabaceae and a species of caesalpinioideae. The DR fruit is green and flaccid in its earlier stage that later turns to dark brown color and becomes hard. Caryotta Obtusa (CO) is commonly known as the giant black fishtail palm tree which is shown in Fig. 1e. The tree grows up to $12-20 \mathrm{~m}$ height and the width of the trunk part of the tree grows up to $60-80 \mathrm{~cm}$. The trunk is covered with black fiber which is used as the reinforcement for making composites. Plant fibers such as Sterculia foetida, delonix regia and caryotta obtusa are available in abundance in India and in many other countries including Australia, Bangladesh, Indonesia, Kenya, Malasiya, Myanmar, Indochina, United States, Oman, Pakistan, Philippines, Somalia, Sri Lanka, Thailand, Uganda,, Yemen, Tanzania, Djibouti, Eritrea and Ethiopia at lot quantity $[12,13]$. Human hair is a natural micro fiber formed of keratin with a-helix structure and is primarily composed of three main components: cuticle, cortex and medulla. Cortex is responsible for the mechanical property of hair. Human hair is very strong in tension and it has ability to intact even after several years of an individual's death due to the presence of high amino acid cystine content. Dumping of human hair waste in open fields creates tremendous environmental problems, which can be reduced when using hair as the reinforcement in composites. Also it has significant physical properties such as resistance to stretching, elasticity and hydrophobicity compared to other natural fibers [14-16]. Addition of human hair fiber as a reinforcement in composite makes composites as a homogeneous and isotropic materials. When failure of composite starts under external loads, the randomly oriented human hair micro fiber resist the crack propagation thus resulting in improved strength of the composites. Currently the human hair reinforced composite was used in construction, molded furniture and automobiles applications [17]. A feasibility study was conducted on human hair for evaluating the impact of using it as a reinforcement fiber and concluded that the human hair is suitable as reinforcement material in polymer composites due to its excellent physical, mechanical and thermal properties [15]. The hair damages depend on the presence of product of disulfide oxidation of the amino acid cystine content in hair [18]. In order to evaluate the effectiveness of hair as reinforcement material, $\mathrm{NaOH}$ treatment was performed on the human hair to determine the changes in its structural properties.

Fourier Transform Infrared Spectroscopy (FTIR) is used for the identification of the functional groups bond structure of fiber through the Infrared (IR) absorption bands. Organic material absorbs and converts infrared radiation into vibration according to the chemical bond structure of the atom. The wave lengths obtained by the molecule depend on the masses and type of bond structure which may vary throughout the material. FTIR analysis shows effective interactions and transformation of untreated fiber and treated fiber [19]. FTIR study made on treated and untreated bamboo fiber showed the alkali treated bamboo fiber having certain functional groups such as cellulose, hemi cellulose and lignin removed from the fiber $[20,21]$. The effect of alkali treatment on Dracaena reflex fiber results in removal of excess amorphous constituents and also the infrared spectrum were able to penetrate more in treated fiber when compared to untreated fiber [22]. Tensile test of single sisal fiber carried out under different gauge lengths $(10,20,30$ and $40 \mathrm{~mm})$ yielded tensile strength between 300-400 MPa [23]. Single fiber tests were conducted on three types of flax fiber including dry flax fiber, enzyme retted fiber and water retted fiber. Results showed $67-81 \%$ reduction in the diameter of fiber for enzyme retted fiber and $39-51 \%$ for water retted flax fiber than dry flax fiber [24]. In this research work, the effectiveness of human hair, delonix regia, caryotta obtusa and sterculia foetida fibers were 


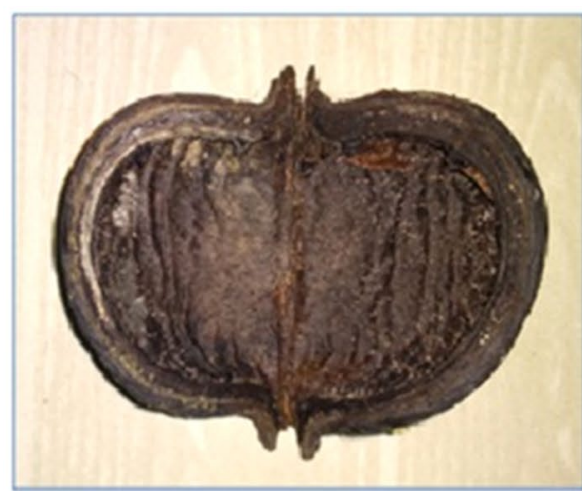

(a) Sterculia Foetida Shell

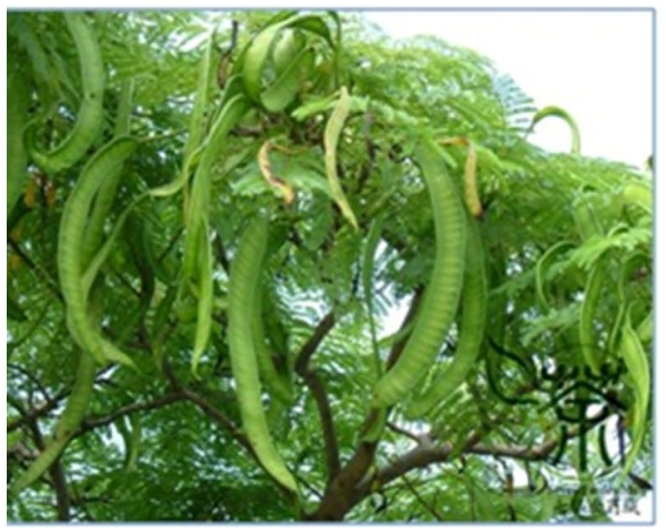

(c) Delonix Regia tree with Fruit

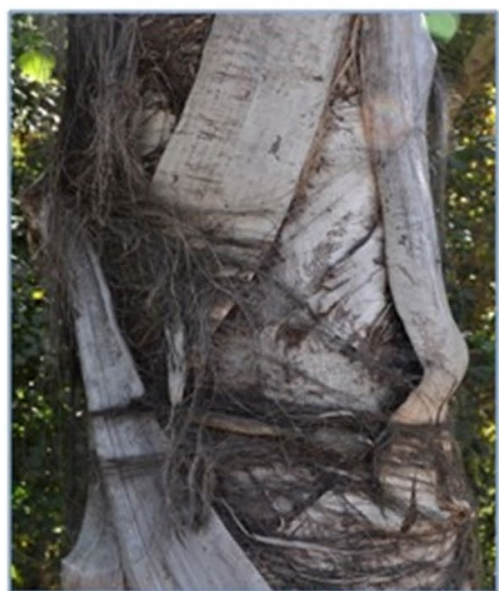

(e) Caryotta Obtusa tree covered with fibers at trunk

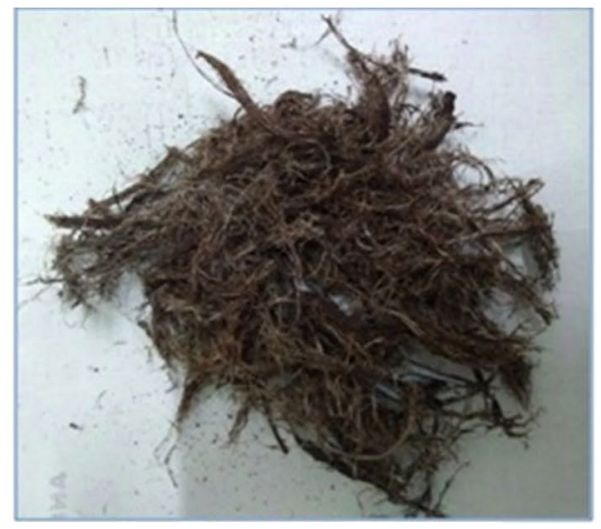

(b) Sterculia Foetida Fiber Extracted from Shell

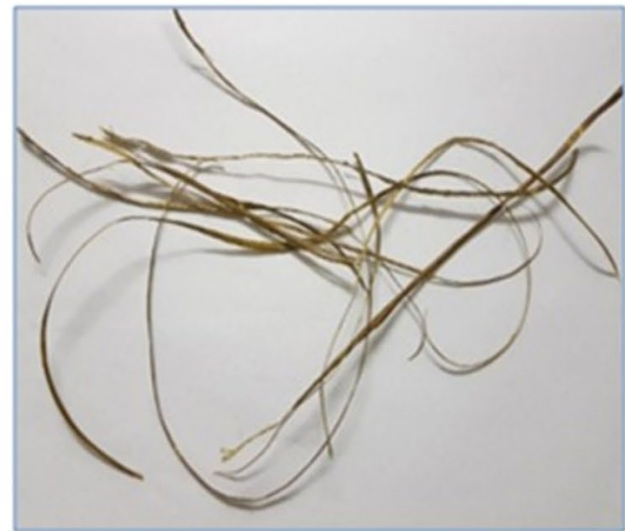

(d) Extracted Delonix Regia Fiber from Fruit

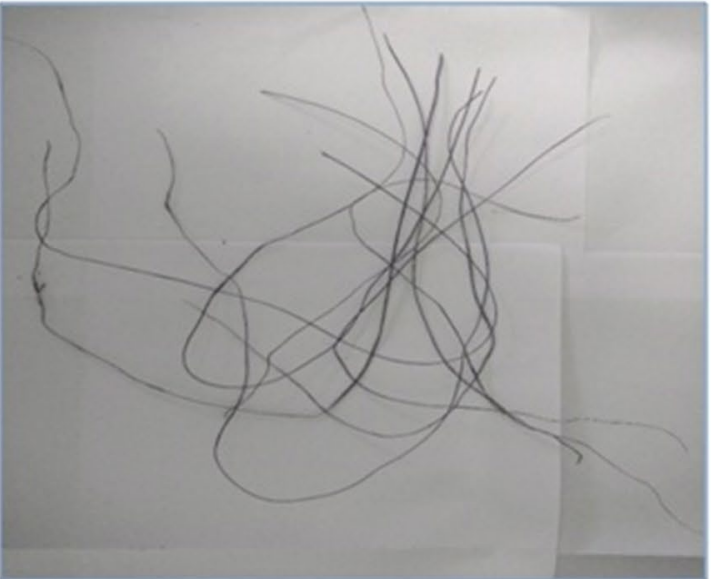

(f) Extracted Caryotta Obtusa Fiber

Fig. 1 Extraction of natural fibers

evaluated by characterizing the fiber using FTIR spectroscopic analysis and performing single fiber tensile test. The fundamental behavior of natural fibers before and after $\mathrm{NaOH}$ treatment was carried out. Suitability of a fiber to reinforce with polymer matrix was analyzed by comparing the obtained test results with various other natural fiber characterization results which carried out by various researchers. 


\section{Materials and methods}

\subsection{Materials used}

Four types of natural fibers have been used in this study. The shell of the Sterculia foetida is soaked in water for $24 \mathrm{~h}$. Then it is taken out and subjected to the mechanical extraction process that includes hammering the shell in order to loosen the bonding between the fibers. After hammering, the fibers are peeled manually. Then the extracted fibers are made to dry at room temperature for $24 \mathrm{~h}$. Sterculia foetida fiber extracted from the fruit shell of the sterculia plant which is found to range between 60 and $80 \mathrm{~mm}$ in its length and $0.5-0.8 \mathrm{~mm}$ in diameter. Figure $1 \mathrm{a}$, b shows the sterculia foetida shell and extracted fiber from shell respectively. The Delonix Regia fiber is extracted from the carpel of the Delonix Regia (DR) fruit shown in Fig. 1c manually using a knife. Then the extracted fibers were dried at environmental temperature. Figure $1 d$ shows the collection of the delonix regia fiber. The DR leaves, roots, fruits and immature seeds have good medicinal value and are used in treatment of many deceases [13]. The Fig. 1e showed the extracted Caryotta Obtusa fibers which are directly collected from trunk part of the CO tree Shown in

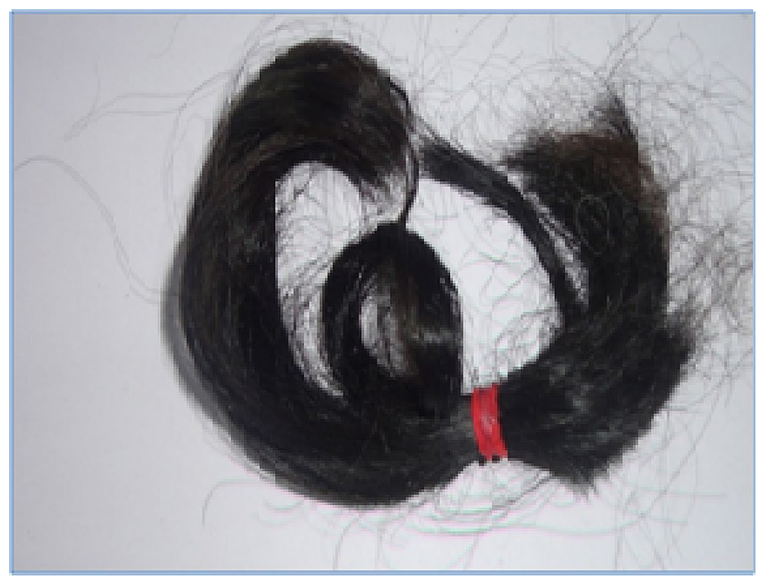

Fig. 2 Collected human hair
Fig. 1f. These fibers are found to be strong with length up to $170 \mathrm{~mm}$. Among the different species of the $\mathrm{CO}$ tree, the fiber obtained from the trunk has better fiber properties due to its high elastic nature and high aspect ratio [25]. So the $\mathrm{CO}$ fiber is tested for its behavior and the possibility of its reinforcement with the polymer matrix. Human hair was collected from a local hair supplier. Figure 2 shows the Human hair used for this study.

Alkaline treatment was performed on the fibers used in this study including Sterculia foetida, Delonix Regia, Caryotta Obtusa and human hair with $\mathrm{NaOH}$. Fiber samples were treated with $5 \%$ concentrated $\mathrm{NaOH}$ solution in water for $4 \mathrm{~h}$. Following this chemical treatment, the fibers were washed with distilled water and then by normal water. Finally the treated fibers were dried at room temperature.

\subsection{Physical property of natural fibers}

The natural fibers such as Human Hair, Sterculia Foetida, Delonix Regia and Caryotta Obtusa were tested for various physical properties such as density, fiber diameter and fiber length. Three fiber samples from each natural fiber were tested and the average values are shown in Table 1. The fiber diameter was measured at different locations along the fiber length using a video measuring system. The fiber length in longitudinal direction was measured using a standard centimeter scale. Density was calculated using liquid immersion technique according to the standard ASTM C 693. The density of the fiber can be calculated in different ways such as diameter and linear density, Archimedes, helium pycnometry, gradient column and liquid pycnometry. The simplest method is the liquid immersion technique (liquid pycnometry) in which the calculated fiber was completely immersed in water and the volumetric displacement was observed [26-28]. It was found by Troung et al. (2009) that during density measurement of flax fiber through liquid pycnometry method, the porosity of the natural fibers were not influenced the density during measurement and the density value obtained was considered as the absolute density of the natural fibers [27]. The mass of the fiber immersed in water divided

Table 1 Physical property of fibers

\begin{tabular}{|c|c|c|c|c|c|c|c|c|}
\hline \multirow[t]{2}{*}{ Fiber type } & \multicolumn{2}{|c|}{ Fiber density $\left(\mathrm{g} / \mathrm{cm}^{3}\right)$} & \multicolumn{5}{|c|}{ Fiber diameter $(\mu \mathrm{m})$} & \multirow[t]{2}{*}{ Fiber length (mm) } \\
\hline & Before alkali & $\begin{array}{l}\text { After alkali } \\
\text { (for } 4 \mathrm{~h} \text {.) }\end{array}$ & $\begin{array}{l}\text { Standard } \\
\text { deviation }\end{array}$ & Before alkali & $\begin{array}{l}\text { Standard } \\
\text { deviation }\end{array}$ & After alkali & $\begin{array}{l}\text { Standard } \\
\text { deviation }\end{array}$ & \\
\hline Human hair & 1.32 & 1.115 & 0.1025 & $17-110$ & 0.021 & $20-97$ & 0.0183 & $20-300$ \\
\hline Sterculia Foetida & 0.87 & 0.83 & 0.02 & $280-700$ & 0.2749 & $260-0.590$ & 0.2389 & $60-100$ \\
\hline Delonix Regia & 0.75 & 0.72 & 0.015 & $300-900$ & 0.3098 & $190-870$ & 0.2126 & $50-200$ \\
\hline Caryotta Obtusa & 0.78 & 0.73 & 0.025 & $370-580$ & 0.1043 & $200-490$ & 0.1203 & $50-150$ \\
\hline
\end{tabular}


by the volume of water rise after immersing the weighed fiber in water yielded the density value. Ovat et al. (2016) used liquid immersion technique to find the density of bamboo fiber and they reported that determined density of different bamboo fiber samples were almost same and also the values were similar to the previously published density value [29]. Density of fibers were calculated using the following formula,

Density $=$ Mass $(\mathrm{m}) /$ Volume $(\mathrm{V})=18.486 / 26.41=0.7 \mathrm{~g} / \mathrm{cm}^{3}$

where ' $m$ ' is mass of the fiber in gram and ' $V$ ' is volume of water rise in beaker (500 ml Borosil IS 2619/ISO 3819) in $\mathrm{cm}$. Volume is calculated using the formula,

Volume $=\pi * \mathrm{r}^{2} * \mathrm{~h}=\pi \times 4.1^{2} \times 0.5=26.41 \mathrm{~cm}^{3}$

where ' $r$ ' is the Radius of beaker in $\mathrm{cm}$ and ' $h$ ' is the height of water rise in beaker in $\mathrm{cm}$.

In the present study, the density of the natural fibers obtained were comparatively very low compared to other natural fibers such as coconut fiber, bamboo, palm, sisal, banana and hemp which is shown in Table 2 . Variations in the fiber diameter along the fiber length were observed when measuring different specimens of the fiber. This may be due to the process of fiber extraction, age of plant and moisture present in the fiber [30]. The mean diameter was taken as the average of three measuring points.

\subsection{Fourier transform infra-red spectroscopy}

The functional groups and this molecular bond structure of the treated and untreated natural fibers were determined using FTIR analysis. FT/IR 4700 type-A model was used for obtaining the Infrared spectrum of fibers in the range of $4000 \mathrm{~cm}^{-1}$ to $600 \mathrm{~cm}^{-1}$. The sample for FTIR was prepared by mixing natural fiber powder sample of approximately $0.5 \mathrm{mg}$ with $100 \mathrm{mg}$ of potassium bromide $(\mathrm{KBr})$. Then the mixture of the samples was placed inside the sample holder and vacuum pressure was applied for removing the moisture that present inside the spectroscopy. Then the infrared laser was projected on to the sample for obtaining the FTIR spectrum of molecules. The absorption bands obtained were analyzed according to the standard ASTM E1252-98(2013)e1 [31].

\subsection{Tensile test}

The treated and untreated natural fibers were subjected to tensile test for determination of the properties such as tensile strength, Young's modulus and percentage elongation. The test was carried out according to the standard ASTM D3379-75 using a universal testing machine $\mathrm{H} 10 \mathrm{KS} / 06-100 \mathrm{~N}$ model. The tensile samples were prepared by attaching both ends of the fiber using a thick paper [32]. The distance between the two thick papers has been considered as the gauge length that is equal to $50 \mathrm{~mm}$ for all the specimens. The loading arrangement of the single fiber tensile test is shown in Fig. 3. The load range of $100 \mathrm{~N}$ and the cross head speed of $5 \mathrm{~mm} / \mathrm{min}$ at the room temperature were applied for performing the test.

\section{Results and discussion}

\subsection{Fourier transform infrared spectroscopic analysis}

Figure 4 show the FTIR spectrum of untreated and treated human hair. A series of bands with different degree of intensity were obtained for treated and untreated hair samples. Table 3 shows the FTIR spectrums of untreated and treated human hair and their characteristics [18, $33-35]$. The band at $3272.61 \mathrm{~cm}^{-1}$ for untreated hair and

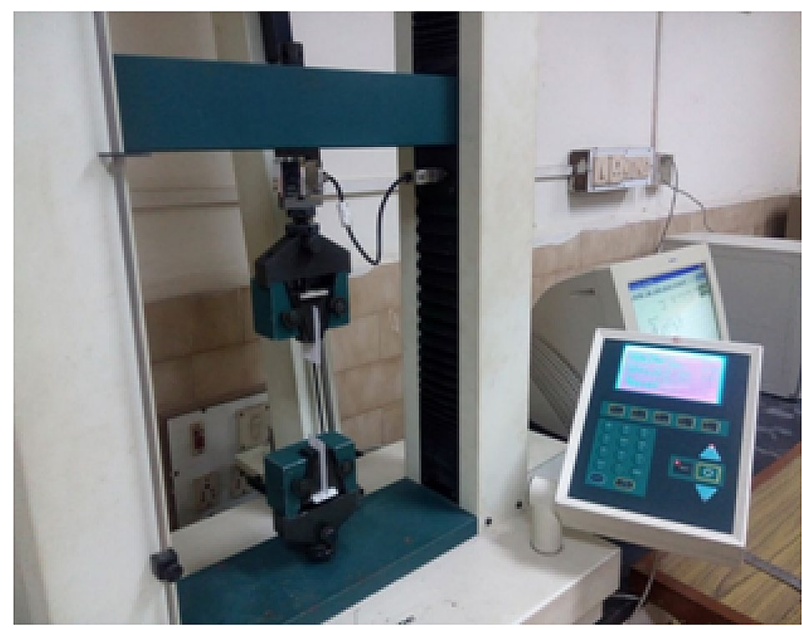

Fig. 3 Arrangements of single fiber tensile testing

Table 2 Comparison of density of fibers with other natural fibers

\begin{tabular}{llllllccc}
\hline Fiber Type & Human Hair & Sterculia Foetida & Delonix Regia & Caryotta Obtusa & $\begin{array}{l}\text { Coir } \\
\text { Literature values [8] }\end{array}$ & Bamboo & Sisal Banana Palm \\
\hline Fiber Density $\left(\mathrm{g} / \mathrm{cm}^{3}\right)$ & 1.32 & 0.87 & 0.754 & 0.78 & 1.15 & 0.91 & 1.45 & 1.35 \\
\hline
\end{tabular}


Fig. 4 FTIR spectrum of untreated and treated human hair

\section{FTIR of Treated Vs. Untreated HH}

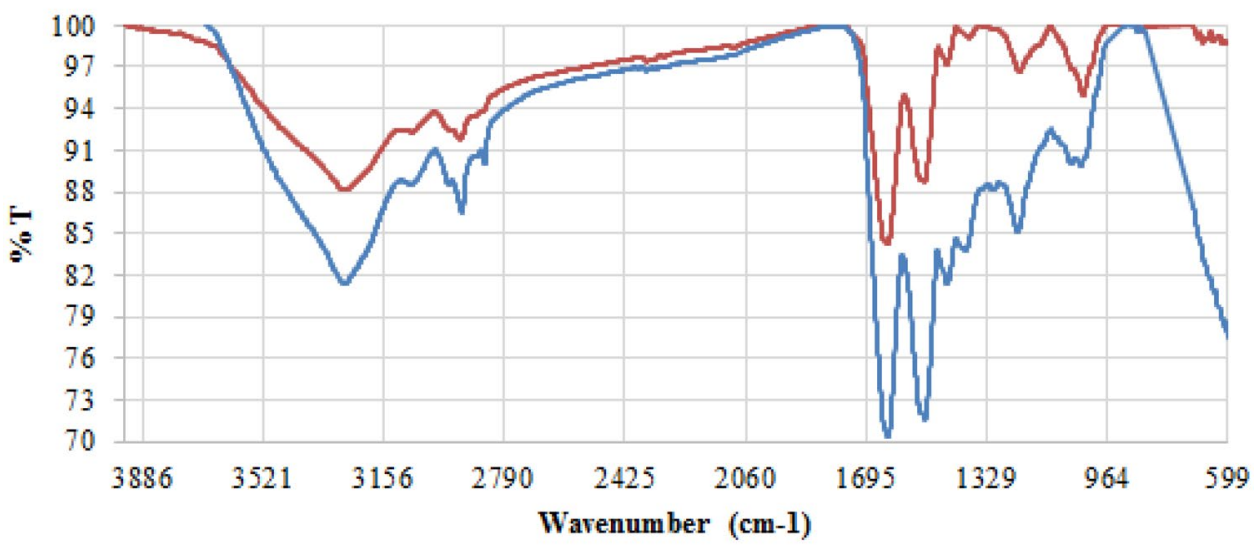

-UnTreated $\mathrm{HH} \quad$ Treated $\mathrm{HH}$

Table 3 FTIR spectrum and its characteristics of untreated and treated human hair

Functional group

Wave number of absorbed spectrum $\left(\mathrm{cm}^{-1}\right)$

\begin{tabular}{ll}
\hline Untreated fiber & Treated fiber \\
\hline 3272.61 & 3270.68 \\
2924.52 & $2918.73,2850.27$ \\
1631.48, & 1631.48, \\
1518.67 & 1516.74 \\
1452.14, & 1452.14 \\
1231.33 & 1235.18 \\
1037.52 & 1044.26
\end{tabular}

$3270.68 \mathrm{~cm}^{-1}$ for treated human hair is related to the carboxylic groups and the $\mathrm{O}-\mathrm{H}$ stretching vibrations that contain water, alcohol and phenol. The wave number $2924.52 \mathrm{~cm}^{-1}$ observed for untreated hair was due to the symmetric vibrations in lipids and $\mathrm{C}-\mathrm{H}$ symmetric stretching of $\mathrm{CH}_{2}$. There were additional peaks at wave numbers of $2918.73 \mathrm{~cm}^{-1}$ and $2850.27 \mathrm{~cm}^{-1}$ was observed for treated human hair at this functional group region. This was due to the $\mathrm{NaOH}$ treatment that create absorption band that causes $\mathrm{C}-\mathrm{H}$ stretching vibrations of lipid acyl $\mathrm{CH}_{2}$ groups [36]. The absorption peak at $1631.48 \mathrm{~cm}^{-1}$ was observed for both untreated and treated human hair, which may be originated due to amide I band components $\beta$ region pleated structure that confirms the presence of proteins. Subsequent bands were observed at $1518.67 \mathrm{~cm}^{-1}$ and $1516.74 \mathrm{~cm}^{-1}$ for untreated and treated human hair respectively. This region was concerned with amide II peak region consisting functional groups of protein $\mathrm{NO}_{2}$ bond in nitro compounds and some carboxylic acids. The peak at $1452.14 \mathrm{~cm}^{-1}$ for both treated and untreated fiber is characterized as $\mathrm{CH}_{2}, \mathrm{CH}_{3}$ asymmetric bending modes of lipids and proteins. The absorption band at $1231.33 \mathrm{~cm}^{-1}$ and $1235.18 \mathrm{~cm}^{-1}$ for untreated hair and treated hair respectively is due to the amide II band groups of proteins and $\mathrm{C}-\mathrm{N}$ stretching vibrations from free amino acids. The absorption band obtained at $1037.52 \mathrm{~cm}^{-1}$ for untreated hair and $1044.26 \mathrm{~cm}^{-1}$ for treated hair is related to $\mathrm{C}-\mathrm{N}, \mathrm{C}-\mathrm{C} \mathrm{C}-\mathrm{O}$ stretching vibrations of carbohydrates which are described to be glucose [37].

The absorption bands obtained from both the untreated and the treated human hair showed decrease in intensity of bands for treated human hair compared to untreated human hair. This was due to the removal of some cystine content in the cuticle cell and the breaking down of a part of the hydrogen bonding in hair structure [18]. The spectra of treated and untreated human hair indicate the presence of keratin content in a large quantity and glucose in a small quantity. An additional peak was observed for treated human hair where the functional groups of symmetric stretching vibrations of $\mathrm{C}-\mathrm{H}$ and lipids were found [35]. 
The FTIR spectra of untreated and treated delonix regia fiber are shown in Fig. 5. This figure showed the different absorption bands as in the ranges $4000 \mathrm{~cm}^{-1}$ to $600 \mathrm{~cm}^{-1}$. The absorption band at $3290.93 \mathrm{~cm}^{-1}$ for untreated delonix regia and at $3281.29 \mathrm{~cm}^{-1}$ for treated delonix regia was observed. The broad absorption band at the region $3500 \mathrm{~cm}^{-1}$ to $3100 \mathrm{~cm}^{-1}$ for both untreated and treated fibers was due to hydroxyl $(\mathrm{OH})$ stretching vibrations. The $\mathrm{O}-\mathrm{H}$ stretching is mainly associated with the presence of functional groups of phenols, alcohol and water. Table 4 shows the FTIR characteristics of treated and untreated delonix regia fiber $[20,38]$. The absorption peak at $2916.81 \mathrm{~cm}^{-1}$ for untreated DR and $2916.81 \mathrm{~cm}^{-1}$ and $2844.49 \mathrm{~cm}^{-1}$ for treated DR was attributed due to the $\mathrm{C}-\mathrm{H}$ stretching that contains functional groups of cellulose and lignin. Khalil et al. (2013), have reported the peak at this region as also due to the functional group of methyl $\left(\mathrm{CH}_{3}\right)$, methylene $\left(\mathrm{CH}_{2}\right)$ and aliphatic saturated $\left(\mathrm{CH}_{3}\right)$ [39]. The FTIR spectrum observed at $1446.35 \mathrm{~cm}^{-1}$, $1372.1 \mathrm{~cm}^{-1}$ and $1241.93 \mathrm{~cm}^{-1}$ for untreated DR was due to the functional groups of alkenes (lignin) characterized as the $C=C$ stretching bond structure. $A$ combination of these three peaks forms as a single peak for treated DR at $\mathrm{C}=\mathrm{C}$ stretching bond structure with a wave number of $1644.02 \mathrm{~cm}^{-1}$. There is yet another combination of three peaks at $1446.35 \mathrm{~cm}^{-1}, 13,725.1 \mathrm{~cm}^{-1}$ and $1241 . j 093 \mathrm{~cm}^{-1}$ for untreated DR were attributed to the $\mathrm{C}-\mathrm{H}$ bending bond that contains the functional groups of cellulose, hemi cellulose and lignin. In treated DR the $\mathrm{C}-\mathrm{H}$ bending was observed at $1420.32 \mathrm{~cm}^{-1}$ and $1319.07 \mathrm{~cm}^{-1}$. The peaks at $1031.73 \mathrm{~cm}^{-1}$ for untreated DR and $1030.77 \mathrm{~cm}^{-1}$ for treated DR indicate the $\mathrm{C}-\mathrm{O}$ stretching bond structure from the functional group of cellulose, hemi cellulose and lignin [40]. The band at $830.205 \mathrm{~cm}^{-1}$ and $669.178 \mathrm{~cm}^{-1}$ for treated DR has been identified as $\mathrm{C}-\mathrm{H}$ out of plane bending bond structure of functional group of lignin. This was disappears in untreated DR fiber. Table 4 shows a reduction in the intensity of peaks after alkaline treatment. Alkali treatment of fibers reduces the moisture absorption compared to the untreated fibers which is shown in the Table 5 . It results in the decrease in intensity of peaks in treated fibers than the untreated fibers. There was a decrease in the number of peaks at $\mathrm{C}=\mathrm{C}$ Stretching and $\mathrm{C}-\mathrm{H}$ bond structure following the treatment of the fiber with sodium hydroxide solution [41].
Fig. 5 FTIR spectrum of untreated and treated Delonix Regia

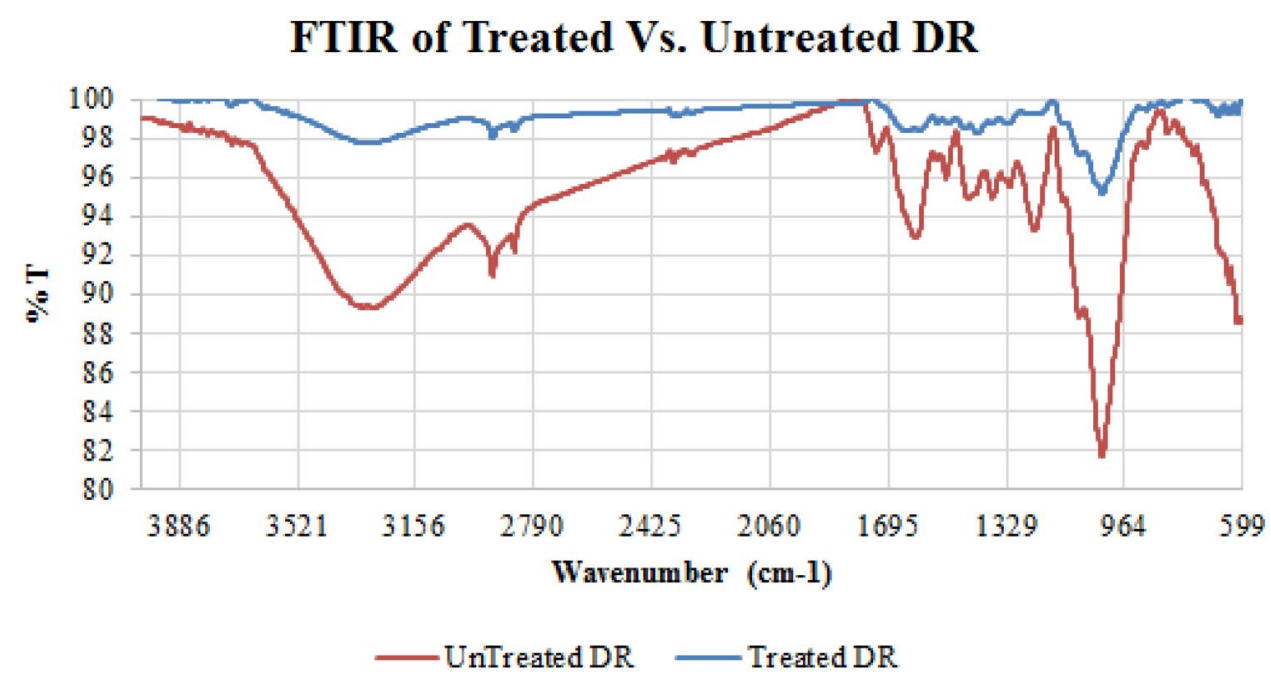

Table 4 FTIR spectrum and its characteristics of untreated and treated Delonix Regia fiber

\begin{tabular}{lll}
\hline Functional group & \multicolumn{1}{c}{ Wave number of absorbed spectrum $\left(\mathrm{cm}^{-1}\right)$} \\
\cline { 2 - 3 } & Untreated fiber & Treated fiber \\
\hline O-H Stretching, H bonded (Alcohol, Water, Phenols) & 3290.93 & 3281.29 \\
C-H Stretching-Alkanes (CH, $\mathrm{CH}_{2}$ and CH $\mathrm{C}_{3}$ ), Carboxylic Acids & 2916.81 & $2916.81,2844.49$ \\
$\mathrm{C}=\mathrm{C}$ Stretching-Alkenes (Lignin) & $1730.8,1611.23,1515.78$ & 1644.02 \\
C-H bending-Alkanes (Cellulose, Hemi cellulose and Lignin) & $1446.35,1372.1,1241.93$ & $1420.32,1319.07$ \\
C-O Stretching-Alcohol (Cellulose, Hemi cellulose, lignin), Carboxylic Acids, & 1031.73 & 1030.77 \\
Esters, Ethers & & $830.205,669.178$ \\
C-H-Aromatic (Lignin) & - &
\end{tabular}


Figure 6 show the FTIR spectrum of untreated and treated caryotta obtusa (CO) fiber. The absorption bands obtained between the ranges $4000 \mathrm{~cm}^{-1}$ to $600 \mathrm{~cm}^{-1}$ have been identified as showed similar band structures obtained for delonix regia fiber. The difference is the number of peaks at different band structure varied for the $\mathrm{CO}$ fiber. The first peak at $3290.93 \mathrm{~cm}^{-1}$ for untreated Caryotta
Obtusa (CO) fiber and at $3279.36 \mathrm{~cm}^{-1}$ for treated Caryotta Obtusa (CO) fiber was observed due to the hydroxyl $(\mathrm{OH})$ stretching vibrations that contain functional groups of phenols, alcohol and water. Table 6 shows the FTIR characteristics of treated and untreated caryotta obtusa fiber $[20,38]$. The absorption band at $2919.7 \mathrm{~cm}^{-1}$ for untreated CO and $2917.77 \mathrm{~cm}^{-1}$ for treated CO is attributed
Table 5 Percentage moisture absorption of fibers before and after alkali treatment

Fig. 6 FTIR spectrum of untreated and treated Caryotta Obtusa

\begin{tabular}{lllllllllll}
\hline Sample & \multicolumn{2}{l}{ \% moisture absorption on every 24 $\mathrm{h}$} \\
\cline { 2 - 10 } & Day 1 & Day 2 & Day 3 & Day 4 & Day 5 & Day 6 & Day 7 & Day 8 & Day 9 & Day 10 \\
\hline HH UT & 0.2590 & 0.1640 & 0.2170 & 0.1460 & 0.1400 & 0.0700 & 0.0523 & 0.0349 & 0.0261 & 0.0087 \\
HHT1 & 0.1440 & 0.0750 & 0.0460 & 0.0260 & 0.0140 & 0.0120 & 0.0174 & 0.0086 & 0.0086 & 0.0000 \\
HHT2 & 0.0840 & 0.0270 & 0.0570 & 0.0290 & 0.0400 & 0.0480 & 0.0480 & 0.0349 & 0.0215 & 0.0080 \\
HHT3 & 0.1570 & 0.1040 & 0.0700 & 0.0370 & 0.0110 & 0.0130 & 0.0243 & 0.0110 & 0.0021 & 0.0022 \\
HHT4 & 0.2500 & 0.0550 & 0.0630 & 0.0680 & 0.0830 & 0.0310 & 0.0506 & 0.0322 & 0.0183 & 0.0285 \\
UTS & 1.0595 & 0.4032 & 0.3213 & 0.2402 & 0.1597 & 0.1595 & 0.0000 & 0.1590 & 0.1587 & 0.0000 \\
TS & 0.3711 & 0.0924 & 0.0923 & 0.0923 & 0.0000 & 0.0922 & 0.0000 & 0.0000 & 0.0000 & 0.0000 \\
UTDR & 0.5830 & 0.2170 & 0.1290 & 0.2060 & 0.0680 & 0.1070 & 0.0684 & 0.0301 & 0.0165 & 0.0110 \\
TDR & 0.4700 & 0.1790 & 0.2560 & 0.0970 & 0.2150 & 0.1240 & 0.0785 & 0.0512 & 0.0271 & 0.0150 \\
UTCO & 2.3386 & 0.3278 & 0.4847 & 0.3707 & 0.2363 & 0.3131 & 0.3164 & 0.1577 & 0.1856 & 0.1033 \\
TCO & 0.5085 & 0.2530 & 0.1682 & 0.1679 & 0.0838 & 0.1675 & 0.0000 & 0.0835 & 0.0835 & 0.0000 \\
\hline
\end{tabular}

FTIR of Treated Vs. Untreated CO

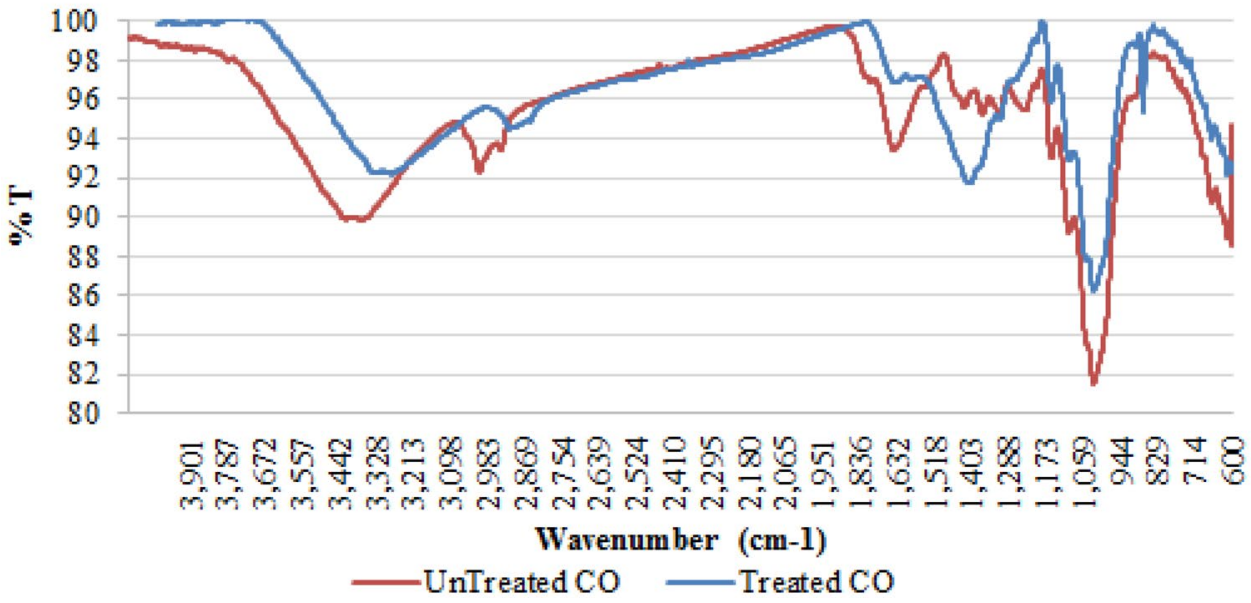

Table 6 FTIR spectrum and its characteristics of untreated and treated caryotta obtusa fiber

\begin{tabular}{|c|c|c|}
\hline \multirow[t]{2}{*}{ Functional group } & \multicolumn{2}{|c|}{ Wave number of absorbed spectrum $\left(\mathrm{cm}^{-1}\right)$} \\
\hline & Untreated fiber & Treated fiber \\
\hline O-H Stretching, $\mathrm{H}$ bonded (Alcohol, Water, Phenols) & 3290.93 & 3279.36 \\
\hline C-H Stretching-Alkanes $\left(\mathrm{CH}, \mathrm{CH}_{2}\right.$ and $\left.\mathrm{CH}_{3}\right)$, Carboxylic Acids & 2919.7 & 2917.77 \\
\hline $\mathrm{C}=\mathrm{C}$ Stretching一Alkenes (Lignin) & 1644.02 & 1644.02 \\
\hline C-H bending -Alkanes (Cellulose, Hemi cellulose and Lignin) & $1371.14,1318.11,1243.86$ & 1414.53 \\
\hline $\begin{array}{l}\text { C-O Stretching-Alcohol (Cellulose, Hemi cellulose, lignin), Carboxylic Acids, } \\
\text { Esters, Ethers }\end{array}$ & $1158.04,1027.87$ & $1158.04,1027.87$ \\
\hline $\mathrm{C}-\mathrm{H}-$ Aromatic (Lignin) & 602.646 & 874.56 \\
\hline
\end{tabular}


to the $\mathrm{C}-\mathrm{H}$ stretching of functional groups of cellulose and lignin. It is also due to the functional group of methyl $\left(\mathrm{CH}_{3}\right)$, methylene $\left(\mathrm{CH}_{2}\right)$ and aliphatic saturated $\left(\mathrm{CH}_{3}\right)$. The band at $1644.02 \mathrm{~cm}^{-1}$ was observed for both untreated $\mathrm{CO}$ and treated $\mathrm{CO}$ was characterized as $\mathrm{C}=\mathrm{C}$ stretching bond structure containing the functional groups of alkenes (lignin). The absorption peaks at $1371.14 \mathrm{~cm}^{-1}$, $1318.11 \mathrm{~cm}^{-1}$ and $1243.86 \mathrm{~cm}^{-1}$ for untreated $\mathrm{CO}$ are characterized as the $\mathrm{C}-\mathrm{H}$ bending bond structure that contains functional groups of cellulose, hemicelluloses and lignin. A combination of these three peaks was formed as a single peak for treated $\mathrm{CO}$ at the wave number of $1414.53 \mathrm{~cm}^{-1}$. There was an another combination of two peaks at $1158.04 \mathrm{~cm}^{-1}$ and $1027.87 \mathrm{~cm}^{-1}$ for both the untreated $\mathrm{CO}$ and the treated $\mathrm{CO}$ were characterized as the $\mathrm{C}-\mathrm{O}$ stretching bond structure which has the functional group of cellulose, hemi cellulose and lignin [43]. The band at $602.646 \mathrm{~cm}^{-1}$ for untreated $\mathrm{CO}$ and $874.56 \mathrm{~cm}^{-1}$ for treated $\mathrm{CO}$ indicates $\mathrm{C}-\mathrm{H}$ out of plane bending bond structure consists the functional group of lignin. The identified absorption bands led to the presence of the same intensity of bands attributed to the $\mathrm{O}-\mathrm{H}$ stretching, $\mathrm{C}-\mathrm{H}$ stretching, $\mathrm{C}=\mathrm{C}$ stretching and $\mathrm{C}-\mathrm{O}$ stretching bond structures. There was a decreased intensity of bands at $1371.14 \mathrm{~cm}^{-1}$ which was characterized as the $\mathrm{C}-\mathrm{H}$ bending bond structures due to the alkaline treatment of fibers that removes some of the cellulose and hemicelluloses contents [44]. The increase in number of peaks and the peak intensity for alkali treated cellulose fibers such as delonix regia and caryotta obtusa resulting in improved surface adhesion between the fiber and the polymer matrix. This promotes the effective stress transfer at interface region of the composite which led to higher mechanical properties of the natural fiber reinforced polymer composites $[6,24$, $33,34]$. Cao et al. (2006) have reported that the mechanical properties of $\mathrm{NaOH}$ treated bagasse fiber reinforced composite observed a $13 \%, 14 \%$ and $30 \%$ improvement in tensile strength, flexural strength and impact resistance respectively [45].

\subsection{Scanning electron microscopic analysis}

The surface morphological analysis of untreated and treated natural fibers such as sterculia foetida, delonix regia and caryotta obtusa were done using Scanning Electron Microscope. It observed the effect on treating the natural fibers with $\mathrm{NaOH}$ with $5 \%$ concentration for 4 h. The Fig. 7 shows the surface morphology of fibers obtained before and after alkali treatment. It can be seen in the Fig. 7a, c, e, the raw fibers (before alkali treated) surface consist many impurities of fibers such as waxes, lignin. While the Fig. 7b, d, f, revealed clean surface with some impurities on the fiber surface. When treating the fiber with $\mathrm{NaOH}$, the hemicellulose breaking and separation of fibers from the fiber bundle occurs at the fiber structure [46]. The fiber separation results in increase in the surface of fiber thus resulting in the improved interlocking of fiber/matrix when reinforcing the fiber with the matrix [47]. The groove like structure in the Fig. 7e is due to the removal of cemantic substances such as lignin and waxes [48].

\subsection{Tensile properties}

\subsubsection{Tensile strength of natural fibers}

Table 7 shows the tensile strength, the Young's modulus and the percentage elongation of both the untreated natural fibers and the natural fibers treated with $5 \% \mathrm{NaOH}$ at $4 \mathrm{~h}$. The results showed, when considering untreated fibers the human hair was seen obtaining higher tensile strength (155-200 MPa) than other natural fibers. The tensile strength of the human hair was seen as $6-11 \%$ higher than the sterculia foetida fiber, 300-350\% higher than the delonix regia and $102-167 \%$ higher than the caryotta obtusa fiber. This helps observation of the delonix regia having obtaining a low tensile strength compared to the other natural fibers considered in this work. This is because of a smaller number of $\mathrm{O}-\mathrm{H}$ bonds, structure and arrangements of fiber molecules that were observed from Fourier Transform Infra-Red (FTIR) Spectroscopy. When treating the fibers with $5 \% \mathrm{NaOH}$ at $4 \mathrm{~h}$, the sterculia foetida fiber was seen getting a higher tensile strength (94-213 MPa) than other natural fibers. Treated Human hair strength was decreased to $23-63 \%$ than the sterculia foetida fiber and $6-11 \%$ than the caryotta obtusa fiber. The value obtained by treated delonix regia fiber lower than that obtained by treated human hair. There was an increase in the tensile strength of plant fibers compared to untreated plant fibers, as a result of the $\mathrm{NaOH}$ treatment of fibers that produces a number of hydrogen bonds that resist the tensile load [49]. Increase in surface area of cellulose fiber reduces the empty spaces between the fiber and matrix thus resulting in improved interlocking of fiber with matrix in the composites [47]. This increases the tensile strength of the treated fiber reinforced composite than the composite with untreated fiber [49]. The tensile strength of the natural fibers used in the present study was comparable to the fibers used as reinforcement in earlier composites. So, the present work natural fibers can be used as reinforcement material and it increases the interaction of fiber with the polymer matrix at the composite interface.

Many researchers have reported that $5 \% \mathrm{NaOH}$ treatment of natural fiber for $4 \mathrm{~h}$ gives better mechanical properties $[42,50]$. In order to evaluate the effect of $\mathrm{NaOH}$ treatment on human hair at different time duration, the human 
Fig. 7 SEM images of a untreated Sterculia Foetida, b Alkali Treated Sterculia Foetida, c untreated Delonix Regia, d alkali treated Delonix Regia, e untreated Caryotta Obtusa and f alkali treated Caryotta Obtusa

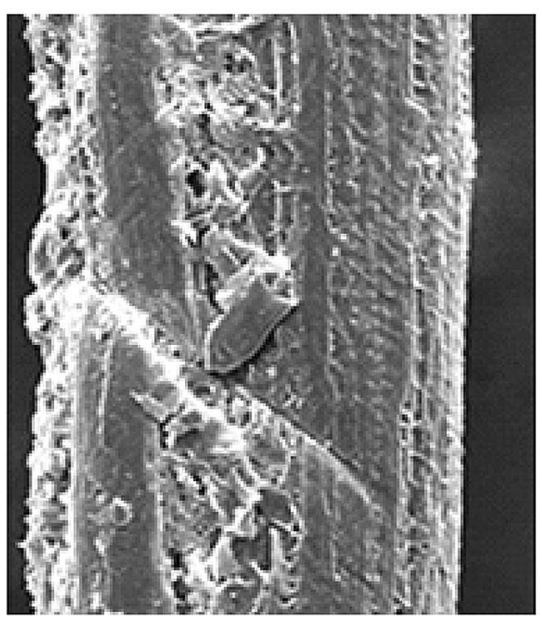

(a)

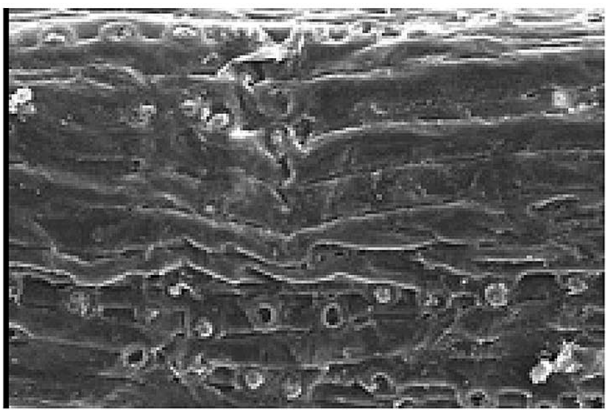

(c)

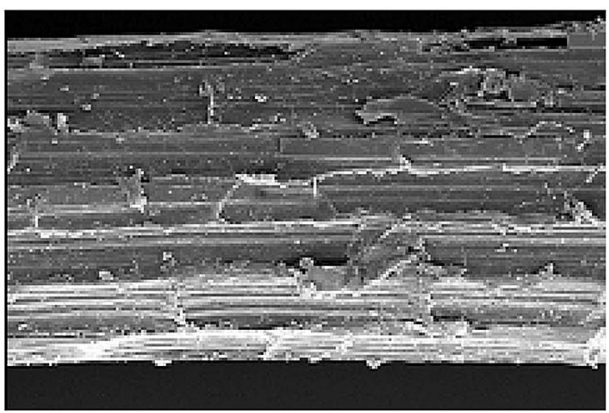

(e)

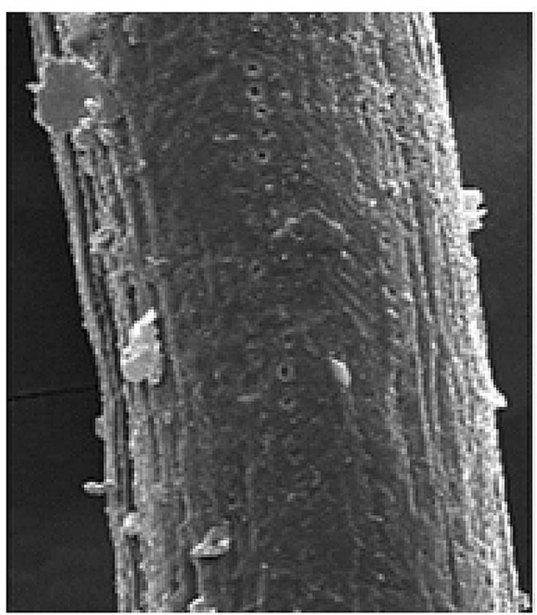

(b)

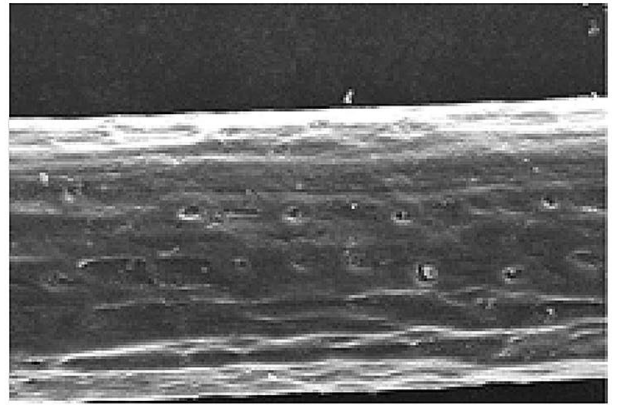

(d)

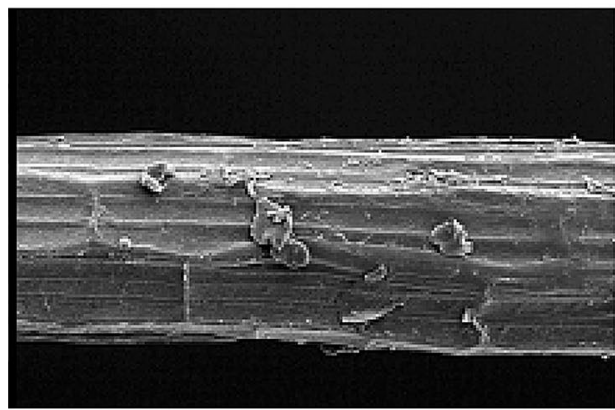

(f)

Table 7 Tensile properties of untreated and treated natural fibers

\begin{tabular}{|c|c|c|c|c|c|c|}
\hline \multirow[t]{2}{*}{ Fiber type and condition } & \multicolumn{2}{|c|}{ Tensile strength (MPa) } & \multicolumn{2}{|c|}{ Young's modulus (MPa) } & \multicolumn{2}{|c|}{$\begin{array}{l}\text { Maximum percentage of } \\
\text { elongation (\%) }\end{array}$} \\
\hline & Un treated & $\begin{array}{l}\mathrm{NaOH} \text { treated } \\
\text { for } 4 \mathrm{~h}\end{array}$ & Un treated & $\mathrm{NaOH}$ treated for $4 \mathrm{~h}$ & Un treated & $\begin{array}{l}\mathrm{NaOH} \\
\text { treated } \\
\text { for } 4 \mathrm{~h}\end{array}$ \\
\hline Human hair & $155-200$ & $76-130$ & $187-364$ & $130-145$ & $44-106$ & $52-99$ \\
\hline Sterculia Foetida & $145-180$ & $94-213$ & $2610-5157$ & $2135-4973$ & 8.12 & 11.89 \\
\hline Delonix Regia & $36-45$ & $74-90$ & $900-930$ & $1700-2360$ & $4-5$ & $3.5-4.4$ \\
\hline Caryotta Obtusa & 58-99 & $110-120$ & $680-720$ & $1190-1590$ & $8-15$ & $7-10$ \\
\hline
\end{tabular}

\section{SN Applied Sciences}


hair was treated with $5 \% \mathrm{NaOH}$ concentration in water for $1,2,3$ and $4 \mathrm{~h}$. The tensile strength, the Young's modulus and the percentage elongation of untreated human hair and the human hair treated with $5 \% \mathrm{NaOH}$ for 1, 2, 3 and $4 \mathrm{~h}$ are shown in Table 8. Human hair treated for $1 \mathrm{~h}$ showed a higher tensile strength than the human hair treated for 2, 3 and $4 \mathrm{~h}$. It was $16-22 \%$ higher than for the tensile strength of untreated human hair. Even when treating the human hair up to $3 \mathrm{~h}$, the tensile strength was higher than for the untreated sterculia, delonix regia and caryotta obtusa fibers. Human hair treated for $4 \mathrm{~h}$ shows a significant decrease in tensile strength that caused losses its keratin structure in human hair by degrading amino acid cystine contents in cortical cell [18]. The average tensile strength of natural fibers is shown in Fig. 8. Table 9 shows the comparison of properties between present work natural fibers and other natural fibers. It is seen that the obtained tensile properties were better agreement as compared to other natural fibers. The human hair

Table 8 Tensile properties of untreated and treated human hair

\begin{tabular}{llll}
\hline Fiber type & $\begin{array}{l}\text { Tensile } \\
\text { strength (MPa) }\end{array}$ & $\begin{array}{l}\text { Young's modu- } \\
\text { lus (MPa) }\end{array}$ & $\begin{array}{l}\text { \% Elonga- } \\
\text { tion at } \\
\text { break }\end{array}$ \\
\hline Un treated & $155-200$ & $187-364$ & $44-106$ \\
Treated for 1 h & $180-257$ & $291-632$ & $40-62$ \\
Treated for 2 h & $137-145$ & $208-324$ & $44-66$ \\
Treated for 3 h & $135-138$ & $283-298$ & $46-48$ \\
Treated for 4 h & $76-130$ & $130-145$ & $52-99$ \\
\hline
\end{tabular}

with very lower diameter has shown tensile strength that almost equal to the other natural fibers. Also the cellulose fibers have obtained the properties that comparable to the other natural fibers which previously used as reinforcement material in composites. Coir fiber is used in making suitcases, helmet and furniture applications $[2,51]$. The density and tensile strength obtained for the human hair and sterculia foetida is higher than the coir fiber. Obtained tensile properties of the natural fibers considered for the present work enhances the suitability of the fiber as a reinforcement material in composites.

\subsection{Young's modulus of natural fibers}

The young's modulus of both the untreated and the treated natural fibers are shown in Fig. 9. Human hair obtained lower young's modulus than the cellulose natural fibers. Generally human hair is highly elastic in nature resulting in high strain during tension. Increase in strain rate causes a decrease in young's modulus of the fiber. When treating the human hair with $\mathrm{NaOH}$ for $1 \mathrm{~h}$ young's modulus increased when compared to untreated human hair sample. While the duration of the chemical treatment was increased to 2, 3 and $4 \mathrm{~h}$ subsequently, the young's modulus was found to gradually decrease. When considering the cellulose natural fibers, Young's modulus of the Sterculia foetida fiber was seen as higher than the other cellulose fibers. The treated cellulose fiber shows increase in the young's modulus than the untreated cellulose fibers. This could be due to the eradication of cementite substance in the fiber structure. There was a significant
Fig. 8 Tensile strength of untreated and treated natural fibers

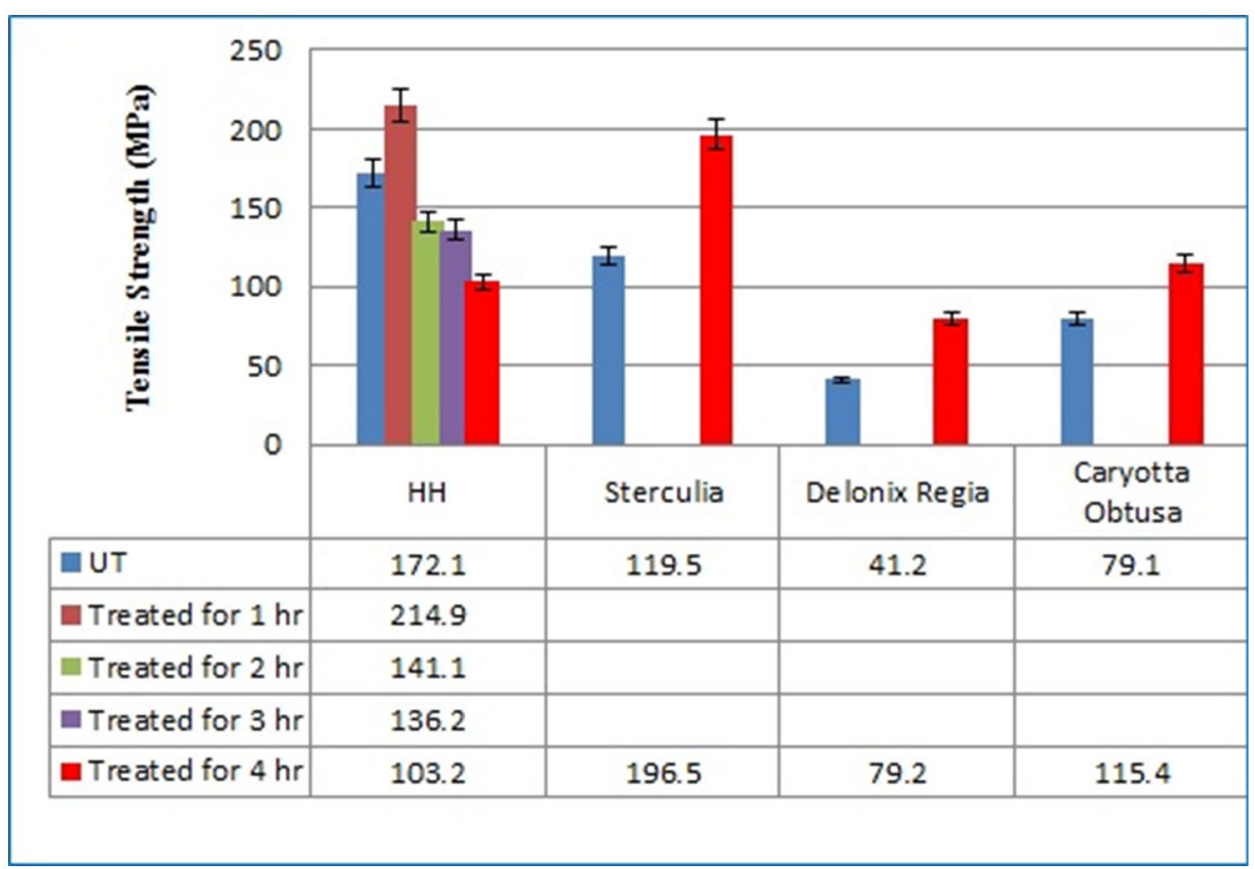


Table 9 Comparison of properties of present work natural fibers with other natural fibers

\begin{tabular}{|c|c|c|c|c|c|c|}
\hline Fibers & Density $\left(\mathrm{g} / \mathrm{cm}^{3}\right)$ & Diameter $(\mu \mathrm{m})$ & $\begin{array}{l}\text { Tensile strength } \\
(\mathrm{MPa})\end{array}$ & $\begin{array}{l}\text { Young's modu- } \\
\text { lus (GPa) }\end{array}$ & $\begin{array}{l}\text { Elongation at } \\
\text { break (\%) }\end{array}$ & References \\
\hline Human Hair & 1.32 & $50-110$ & $155-215$ & $0.28-.45$ & 44-106 & - \\
\hline Sterculia Foetida & 0.87 & $280-700$ & $145-213$ & $2.14-4.97$ & $8.1-11.9$ & - \\
\hline Delonix Regia & 0.754 & $300-900$ & $74-90$ & $1.7-2.4$ & $4-5$ & - \\
\hline Caryotta Obtusa & 0.78 & $370-580$ & $99-120$ & $1.19-1.59$ & $8-15$ & - \\
\hline Coir & 1.31 & $100-460$ & $131-220$ & $4-6$ & $15-40$ & {$[51]$} \\
\hline Oil Palm mesocarp & 1.13 & $150-500$ & 80 & 0.5 & 17 & {$[51,52]$} \\
\hline Kenaf & 0.75 & 83.5 & 282.60 & 7.13 & - & {$[53,54]$} \\
\hline Pineapple Leaf Fiber & 0.95 & 78.8 & 290.61 & 5.38 & $3.1-6.7$ & [54] \\
\hline Conium maculatum & 0.834 & 89.3 & 327.89 & 15.77 & 2.67 & [43] \\
\hline Pennisetum purpureum & 0.92 & 94.3 & 73 & 5.68 & 1.40 & {$[55]$} \\
\hline Sansevieria ehrenbergii & 0.887 & 250 & $50-585$ & $1.5-7.67$ & $2.8-21.7$ & {$[56]$} \\
\hline
\end{tabular}

Fig. 9 Young's modulus of untreated and treated natural fibers

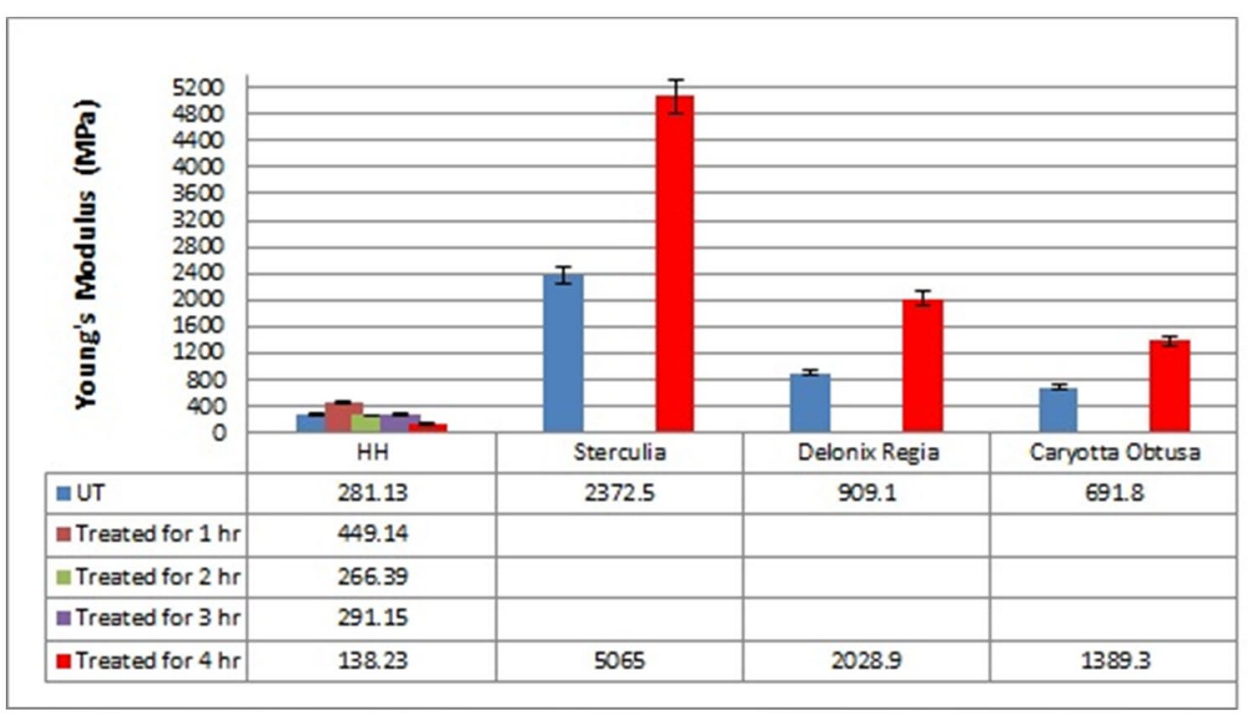

increase in the young's modulus of the treated Sterculia fiber. This could be the result of decrease in the strain of the fiber that resists deformation while stretching the fiber [51].

\subsection{Percentage elongation at fiber braking}

The percentage elongations of the human hair and the cellulose natural fiber samples are shown in Fig. 10. The human hair samples were seen having higher elongation at fiber breaking point in the tensile test. The range of percentage elongation of human hair samples was in the range of $40-106 \%$. No significant variation in elongation was observed between the treated and the untreated human hair samples. Table 7 shows the percentage elongation for treated and untreated human hair samples.

Both the treated and the untreated cellulose fibers showed a smaller elongation when compared to the human hair samples. This increases the young's modulus of cellulose fiber samples. Delonix regia obtained lower percentage elongation than other sterculia foetida and caryotta obtusa fiber. Wei hu et al. (2010), have reported the percentage elongation of flax fiber showing less than $2 \%$ for dry, water retted and enzyme retted flax samples [24]. The result obtained from present work was higher than that of the flax fiber result.

\section{Conclusion}

In this study, natural fibers such as human hair, sterculia foetida, delonix regia and caryotta obtusa fibers were characterized by performing a single fiber tensile test and FTIR analysis. Three samples in each natural fibers were tested and the results concluded as follow. Tensile test results showed delonix regia fibers having lower 
Fig. 10 Percentage elongations of untreated and treated natural fibers at breaking point

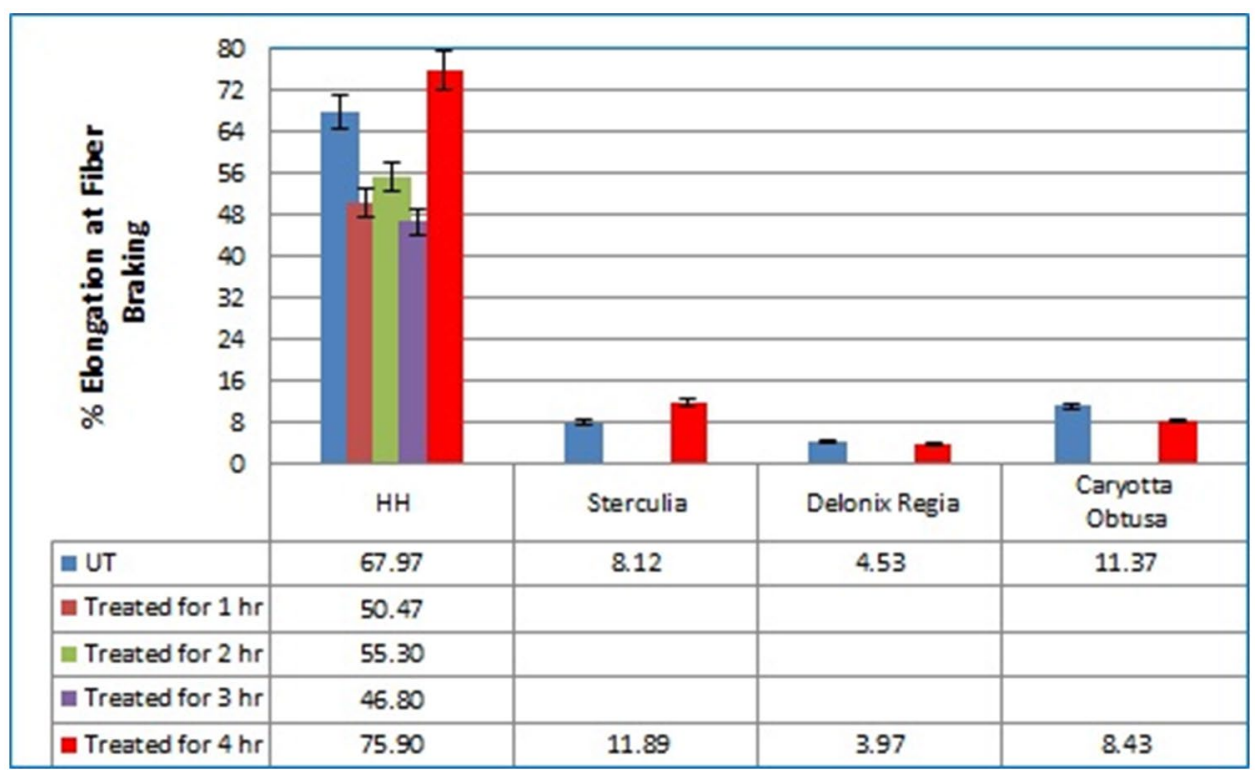

tensile properties than other natural fibers. The tensile strength and the percentage elongation were higher for human hair while the young's modulus was higher for Sterculia foetida fiber. The conclusion for spectroscopic analysis was concluded that the $\mathrm{NaOH}$ treated plant fibers surfaces were exposed due to the removal of hemicellulose, lignin, wax, water and oils. Similarly for $\mathrm{NaOH}$ treated human hair fibers were showed decreases in intensity of spectrum due to the removal of cystine content in cuticle cell and hydrogen debonding. FTIR results confirmed the presence of protein in a large quantity for both the untreated and the treated human hair. Additional peaks were developed for both the treated plant fiber and the hair fiber due to the formation of new molecular structure. $\mathrm{NaOH}$ treatment of fibers showed the exposure of the fiber surface enhancing the fiber interlocking when reinforced with polymer matrix due to increased surface area of the treated fibers. The results showed the fibers used for this research work were found suitable for usage as reinforcement with polymer matrix. The high elastic applications, human hair may be used for the enhancement of vibrational properties of composites. Addition of cellulose fiber and other fillers can increase the stiffness and strength properties of the human hair composites. Cellulose fibers such as sterculia, delonix regia and caryotta obtusa showed better stiffness values equivalent to the stiffness of other natural fibers such as coir, oil palm, Kenaf, conium maculatum, pennisetum purpureum, Sansevieria ehrenbergii, etc. With relevance to the future scope, the fibers are found to be suitable for the applications where the light weight and sufficient strength and stiffness are needed.

\section{Declarations}

Conflict of interest Authors Selvakumar Kathiresan and Omkumar Meenakshisundaram declares that we have no conflict of interest.

Ethical approval This article does not contain any studies with human participants or animals performed by any of the authors.

Open Access This article is licensed under a Creative Commons Attribution 4.0 International License, which permits use, sharing, adaptation, distribution and reproduction in any medium or format, as long as you give appropriate credit to the original author(s) and the source, provide a link to the Creative Commons licence, and indicate if changes were made. The images or other third party material in this article are included in the article's Creative Commons licence, unless indicated otherwise in a credit line to the material. If material is not included in the article's Creative Commons licence and your intended use is not permitted by statutory regulation or exceeds the permitted use, you will need to obtain permission directly from the copyright holder. To view a copy of this licence, visit http://creativecommons. org/licenses/by/4.0/.

\section{References}

1. Hao W, Can T, Yanan Y, Xuefeng Y, Yinji M (2015) Experimental study on the fiber pull-out of composites using digital gradient sensing technique. Polym Testing 41:239-244

2. Sanjay MR, Arpitha GR, Laxmana L (2016) Applications of natural fibers and its composites: an overview. Nat Resour 7:108-114

3. Sanjay MR, Siengchin S, Parameswaranpillai J, Jawaid M, Pruncu $\mathrm{Cl}$, Khan A (2018) A comprehensive review of techniques for natural fibers as reinforcement in composites: preparation, processing and characterization. Carbohydr Polym. https://doi.org/ 10.1016/j.carbpol.2018.11.083

4. Thyavihalli Girijappa YG, Mavinkere Rangappa S, Parameswaranpillai J, Siengchin S (2019) Natural fibers as sustainable and 
renewable resource for development of eco-friendly composites: a comprehensive review. Front Mater 6:226. https://doi.org/ 10.3389/fmats.2019.00226

5. Arkady C, Eugene BA (2014) Combined discrete event, agentbased approach to modeling the tensile strength of one dimensional fibrous materials. J Eng Fibers Fabr 9:1-15

6. Leonard YM, Ansell MP (2002) Chemical modification of hemp, sisal, jute and kapak fibers by alkalization. J Appl Polym Sci 84:2222-2234

7. Xue L, Tabil KG, Sathyanarayan $P$ (2007) Chemical treatments of natural fiber for use in natural fiber reinforced composites: $a$ review. J Polym Sci 15:25-33

8. Maya JJ, Rajesh DA (2008) Recent development in chemical modification and characterization of natural fiber-reinforced composites. Polym Compos 29:187-207

9. Sabela C, Pjilippe V, Christine C (2014) Comparison of bio and eco-technologies with chemical methods for pre-treatment of flax fibers: impact on fiber properties. J Eng Fibers Fabr 9:56-68

10. Paulo RLL, Heni MS, Geany PC (2017) Effect of surface biopolymeric treatment on sisal fiber properties and fiber-cement bond. J Eng Fibers Fabrics 12:59-71

11. Vignesh VP, Omkumar M, Anandakumar S (2017) Scope of sterculia foetida in composites. In: International conference on recent innovations in production engineering (RIPE2017):85

12. Teli MD, Pintu P (2018) Application of Sterculia Foetida fruit shell waste biomolecules on silk for aesthetic and wellness properties. Fibers Polym 19:41-54

13. Oyedeji OA, Azeez LA, Osifade B (2017) Chemical and nutritional compositions of flame of forest (Delonix regia) seeds and seed oil. S Afr J Chem 70:16-20

14. Vishakh R, Arvind M, Mahesh T (2013) Human hair reinforced bio-composites environment friendly advanced light weight composites. Int J Technol Res Eng 1:26-30

15. Akarsh V, Singh VK, Verma SK (2016) Human hair: a biodegradable composite fiber-a review. Int J Waste Resour 6:1-4

16. Ashish Kumar D, Arvind D, Vinodkumar V (2015) Compressive strength evaluation of human hair and polypropylene fabricated reinforced composite. Int J Eng Sci 4:88-91

17. Divakara Rao P, Udayakiran C, Eshwara P (2017) Tensile studies on random oriented human hair fiber reinforced polyester composites. J Mech Eng 47:37-44

18. Soo RR, Wonhyeong J, Yu S (2016) FT-IR microspectroscopic imaging of cross-sectioned human hair during a bleaching process. J Cosmet Dermatol Sci Appl 6:181-190

19. Senthamaraikannan $P$, Kathiresan $M(2018)$ Characterization of raw and alkali treated new natural cellulosic fiber from cocinia grandis. Carbohydr Polym 186:332-343

20. Muhammad KB, Elammaran J (2016) Comparative study of functional groups in natural fibers: Fourier transform infrared analysis (Ftir). Int J Curr Eng Sci Res 3:154-161

21. Sanjay MR, Madhu P, Mohammad Jawaid P, Senthamaraikannan S, Senthil SP (2017) Characterization and properties of natural fiber polymer composites: a comprehensive review. J Clean Prod. https://doi.org/10.1016/j.jclepro.2017.10.101

22. Vinod MRS, Suchart S, Jyotishkumar P (2020) Renewable and sustainable biobased materials: an assessment on biofibers, biofilms, biopolymers and biocomposites. J Clean Prod 258:120978

23. Flavio AS, Nikhilesh C, Romildo TF (2008) Tensile behavior of high performance natural (sisal) fibers. Compos Sci Technol 68:3438-3443

24. Wei H, Minhtan TT, Florence PS (2010) An improved method for single fiber tensile test of natural fibers. Polym Eng Sci 819-825

25. Plants for a future, England, 1996-2012. https://pfaf.org/user/ Plant.aspx?LatinName=Caryota+urens
26. Vivek Kumar S, Agarwal A (2017) An experimental approach for behavior analysis of sisal epoxy composites. Int J Eng Sci Res Technol 6:717-724

27. Truong M, Zhong W, Boyko Mercedes S (2009) Comparative study on natural fiber density measurement. J Text Inst 100:525-529

28. Maelenn LG, Peter D, Christophe B (2018) Recommended flax fiber density value for composite property predictions. Ind Crops Prod 114:52-58

29. Ovat FA, Obto OW, Fakorede DO (2015) Determination of density of Nigerian bamboo fiber as an engineering property using maceration method. Int J Sci Eng Res 6:1811-1822

30. Murali Mohan K, Mohana K (2007) Extraction and tensile properties of natural fibers: Vakka, date and bamboo. Compos Struct 7:288-295

31. ASTM E1252-98(2013)e1, standard practice for general techniques for obtaining infrared spectra for qualitative analysis, ASTM International, West Conshohocken, https://doi.org/10. 1520/E1252-98R13E01

32. Prasannakumar I, Preetamkumar MM, Sudhir K (2012) Axial tensile testing of single fibers. Mod Mech Eng 2:151-156

33. Signori V, Lewis DM (1997) FTIR investigation of the damage produced on human hair by weathering and bleaching processes: implementation of different sampling techniques and data processing. Int J Cosmet Sci 19(1-1):3

34. Lei Z, Saad H (2007) Fourier transform infrared (FTIR) in diabetes research by analyzing hair samples. J N C Acad Sci 123:163-166

35. Mohd A, Mujeeb MKM (2017) FTIR spectroscopic analysis on human hair. Int J Innov Res Sci Eng Technol 6:9327-9332

36. Robbins CR (2012) Chemical and physical behavior of human hair. Springer, Berlin, pp 102-175. https://doi.org/10.1007/ 978-3-642-25611-0_2

37. Chandra M, Pande Brian Y (2000) Near-infrared spectroscopy applications in hair research. J Cosmet Sci 51:183-192

38. Manimaran $P$, Sanjay MR, Senthamaraikannan $P$, Jawaid M, Saravanakumar SS, George R (2018) Synthesis and characterization of cellulosic fiber from red banana peduncle as reinforcement for potential applications. J Nat Fibers 10:10. https://doi.org/10. 1080/15440478.2018.1434851

39. Khalil AS, Rahim AA, Taha KK (2013) Characterization of methanolic extracts of agar wood leaves. J Appl Ind Sci 3:78-88

40. Madhu P, Sanjay MR, Jawaid M, Siengchin S, Khan A, Iulian Pruncu C (2020) A new study on effect of various chemical treatments on Agave Americana fiber for composite reinforcement: physico-chemical, thermal, mechanical and morphological properties. Polym Test 85:106437

41. Jie L, Chuanjie Z, Dagang M (2018) Preparation and characterization of carboxymethyl cellulose hydrogel fibers. J Eng Fibers Fabr 13:6-13

42. Manimaran $P$, Saravanan $S P$, Sanjay $M R$, Siengchin $S$, Jawaid $M$, Khan A (2019) Characterization of new cellulosic fiber: dracaena reflexa as a reinforcement for polymer composite structures. J Mater Res Technol 8(2):1952-1963

43. Ahmet CK, Serhan K, Yasemini S (2018) Extraction and investigation of lightweight and porous natural fiber from conium maculatum as a potential for composite materials in transportation. Compos B 140:1-8

44. Theivasanthi T, Anne FL, Adeleke J (2018) Synthesis and characterization of cotton fiber based nanocellulose. Int J Biol Macromol 109:832-836

45. Cao Y, Shibata S, Fukumoto I (2006) Mechanical properties of biodegradable composites reinforced with bagasse fiber before and after alkali treatments. Compos A 37:423-429

46. Manimaran P, Saravanan SP, Sanjay MR, Jawaid M, Fiore SSV (2019) New lignocellulosic aristida adscensionis fibers as novel reinforcement for composite materials: extraction, 
characterization and weibull distribution analysis. J Polym Environ. https://doi.org/10.1007/s10924-019-01640-7

47. Alshammari BA, Alotaibi MD, Alothman OY, Sanjay MR, Kian LK, Almutairi Z, Jawaid M (2019) A new study on characterization and properties of natural fibers obtained from olive tree (Olea europaea L.) residues. J Polym Environ. https://doi.org/10.1007/ s10924-019-01526-8

48. Saria NH, Sanjay MR, Arpitha GR, Pruncue Cl, Siengchin S (2019) Synthesis and properties of pandanwangi fiber reinforced polyethylene composites: Evaluation of dicumyl peroxide (DCP) effect. Compos Commun 15:53-57

49. Mayandi K, Rajini N, Winowlin JT (2018) Properties of untreated and chemically treated cissus quadraangularis natural fibers and their composites with polyester as the matrix. Polym Compos 39:876-886

50. Syafri E, Kasim A, Abral H, Sudirman GT, Sulungbudi MRS, Sari $\mathrm{NH}$ (2018) Synthesis and characterization of cellulose nanofibers (CNF) ramie reinforced cassava starch hybrid composites. Int J Biol Macromol. https://doi.org/10.1016/j.ijbiomac.2018.08.134

51. Subhankar B, Qumrul A, Ahmed C (2013) Physical and mechanical properties of jute, bamboo and coir natural fiber. Fibers Polym 14:1762-1767
52. Rouison D, Sain N, Couturier M (2004) Resin transfer molding of natural fiber reinforced composites: cure simulation. Compos Sci Technol 64:629-644

53. Akil HM, Omar MF, Mazuki AAM (2011) Kenaf fiber reinforced composites: a review. Mater Des 32:4107-4121

54. Asim M, Jawid M, Khalina, (2016) Effect of alkali and silane treatments on mechanical and fiber-matrix bond strength of Kenaf and pineapple leaf fibers. J Bionic Eng 13:426-435

55. Ridzuan M, Afendi M, Kanfiah, (2013) Characterization of natural cellulosic fiber from Pennisetum purpureum stem as potential reinforcement of polymer composites. Mater Des 89:839-847

56. Sathiskumar TP, Navneethakrihnan P (2013) Characterization of new cellulose Sansevieria ehrenbergii fibers for polymer composites. Compos Interfaces 20:575-593

Publisher's Note Springer Nature remains neutral with regard to jurisdictional claims in published maps and institutional affiliations. 